\title{
ANTARCTIC TREATY AND ANTARCTIC TERRITORY PROTECTION MECHANISMS*
}

\section{TRATADO ANTÁRTICO Y MECANISMOS DE PROTECCIÓN DEL TERRITORIO ANTÁRTICO}

\section{Fernando Villamizar Lamus ${ }^{* *}$}

\begin{abstract}
The Antarctic Treaty marks a fundamental milestone in the handling of Antarctica. This treaty contains some mechanisms that, until now, have been effective in protecting the Antarctic territory. In this article the hows and whys of said mechanisms are laid out. However, at the same time the effectiveness of the mechanisms are only applicable to the states that form part of the Antarctic Treaty. How then would the Antarctic territory be defended with respect to states that are not party to the Antarctic Treaty? The proposed answer to this question consists in confirming that the evolution of the so-called "Question of Antarctica" has generated a custom in international law in such a way that the principles of the Antarctic Treaty are enforceable against third party States that are not party to this treaty.
\end{abstract}

Key words: Antarctic Treaty, International Custom, Antarctic protection mechanisms.

RESUMEN: El Tratado Antártico ha marcado un hito fundamental en el tratamiento de la Antártida. Dicho Tratado posee unos mecanismos que hasta ahora han sido eficaces para proteger el territorio antártico. En el artículo se expone cuáles y cómo operan dichos mecanismos, pero a su vez se prevé que la operatividad de los mecanismos solo es aplicable a los Estados parte del Tratado Antártico. ¿Cómo se defendería entonces el territorio antártico respecto de Estados que no son parte del Tratado Antártico? La respuesta que se plantea a este interrogante consiste en afirmar que la evolución de la llamada "Cuestión Antártica" ha generado costumbre en Derecho Internacional, de manera que los principios del Tratado Antártico son oponibles a terceros Estado que no son parte de dicho tratado.

Palabras clave: Tratado Antártico, Costumbre Internacional, Mecanismos de protección antártica.

\footnotetext{
This article is part of a research project “Cátedra Bernardo O’Higgins” (Bernardo O’Higgins Lectures) in the support of teaching.

The Author wants to thank Mr. Luis Winter, former Chilean diplomat and current Rector at the University of the Pacific (Chile), for the ideas about the protected legal interest.

** Lawyer from the University of Rosario (Bogotá, Colombia), Master of Business Law, Pontifical Catholic University of Chile, Ph.D. in Political Science and Sociology, Pontifical University of Salamanca, Spain. Professor and Researcher at Bernardo O'Higgins University, Professor in Constitutional Law at the University of the Andes (Chile). E-mail: fvillamizar@ubo.cl.
} 


\section{INTRODUCTION}

The classic authors that have worked on state theory, such as Jellinek ${ }^{1}$, Heller ${ }^{2}$, or Carré del Marberg ${ }^{3}$, have been emphatic in proposing that the territory, as an element of the state, requires or necessarily assumes the concept of sovereignty in order for the state to exercise its authority in the said territory. In the area of international public law, the classic authors, such as Oppenheim ${ }^{4}$, L'Huillier ${ }^{5}$, Rousseau ${ }^{6}$, and Verdross ${ }^{7}$ agree with Jellinek and Carré de Malberg in the sense that the state exercises in the territory its supreme authority, in other words its sovereignty, and in this way rules out the sovereignty of every foreign state with the exception of a few.

This postulate, which demands sovereignty as a basic and fundamental element in order for the state to claim territory, is a fundamental principle for the order of the international system in such a way that it is recognized as one of the dogmas of international law ${ }^{8}$ and has been set as precedent in judicial cases such as that of the Island of Palmas. In this case, Judge Huber established that "sovereignty in relation to a portion of the surface of the globe is the legal condition necessary for the inclusion of such portion in the territory of any particular State" .

Given the requirement of sovereignty for the claiming of a determined territory, seven states ${ }^{10}$ have claimed sovereignty over each part of the Antarctic territory. However, in order to avoid territorial disputes over the white continent, twelve states signed the Antarctic Treaty in Washington D.C. in $1959^{11}$, which suspended territorial claims in Antarctica and, additionally, established that "no act or activities taking place while the present Treaty is in force shall constitute a basis for asserting, supporting, or denying a claim to territorial sovereignty in Antarctica or create any rights of sovereignty in Antarctica. No new claim, or enlargement of an existing claim, to territorial sovereignty in Antarctica shall be asserted while the present Treaty is in force" ${ }^{12}$.

\footnotetext{
1 Jellinek (1970) p. 295.

2 Heller (1965).

3 Carré De Malberg (2000) p. 96.

4 Oppenheim (1955) p. 563 et seq.

5 L'Huillier (1950) p. 34 et seq.

6 Rousseau (1961) p. 218 et seq.

7 Verdross (1967) p. 207 et seq.

8 Domingo (2010) p. 73.

9 United States vs. Holland: Permanent Court of Arbitration 1928 (Judge Max Huber, Island of Palmas Case) Rec. Sent. Arbitral. U.N., vol. II. p. 838.

10 They have made claims in the following chronological order: Great Britain (1908), New Zealand (1923), France (1924), Australia (1933), Norway (1939), Chile (1940) y Argentina (1942). Of all the white continent, only $15 \%$ was not claimed.

11 The signing states were: Argentina, Australia, Belgium, Chile, France, Japan, New Zealand, Norway, Union of South Africa (current day Republic of South Africa), the former Union of Soviet Socialist Republics, the United Kingdom, North Ireland and the United States of America.

12 Article IV, Antarctic Treaty of 1959.
} 
When faced with the suspension of territorial claims and the restriction on state sovereignty being exercised in Antarctica, the aforementioned Antarctic Treaty establishes various mechanisms for the protection of the Antarctic territory and in its Article XIII rules that "it shall be open for accession by any State that is a Member of the United Nations, or by any other State which may be invited to accede to the Treaty with the consent of all the Contracting Parties (...)". Subsequently, in addition to the twelve states that were the original signers, 38 states have joined and formed a group of 50 member states of the Antarctic Treaty divided into two categories: Consultative and NonConsultative Parties.

The criteria to designate a party as consultative or non-consultative depends on the scientific activity that it is developing in Antarctica, more specifically: (i) the conducting of important scientific research, (ii) the establishment of a scientific station, or (iii) the dispatch of a scientific expedition. If a state complies with one of the three previously mentioned items, it is considered a Consultative Party and, on the contrary, if it does not carry out any of the aforementioned activities, it is then considered a Non-Consultative Party $^{13}$. Currently, there are 28 Consultative Parties that participate in meetings and can make decisions and 22 Non-Consultative Parties that are invited to attend meetings, but they do not participate in the decision making process.

However, given that not all the states that are members of the United Nations Organization are part of the Antarctic Treaty and the complementary treaties or that some state party can denounce the Antarctic Treaty, the research question that we are attempting to address in this article emerges. It consists in determining if, in the case that the mechanisms of mentioned treaty that are meant to protect the legally protected rights should fail, it could be argued that the Antarctic Treaty, especially the principal of the peaceful usage of Antarctica, constitutes a custom in international law and, therefore, it is the source of valid law enforceable against third party states that are not party to the Antarctic Treaty.

The hypothesis that will guide this work consists in asserting that the protection mechanisms of the Antarctic territory contemplated in the Antarctic Treaty could be insufficient legally against third party states. However, there are arguments to sustain, not without difficulties, that the above mentioned treaty, and mainly the principle of peaceful usage of the Antarctic territory contained in it, has generated a custom in international public law as a general practice and, therefore, with opinio juris is a source of valid international law and enforceable against third state parties that are not part of the Antarctic Treaty.

In order to demonstrate the previous hypothesis, this paper will first show how the decision to sign the Antarctic Treaty was arrived at and the legal rights protected by it. Subsequently, it will analyze the reach of the Antarctic territory's protection mechanisms with respect to that established in the Antarctic Treaty. Thirdly, it will reflect on the arguments in favor of asserting that the Antarctic Treaty has generated custom in international public law for third party states. Finally, it will share the relevant conclusions.

13 Article IX number 2, Antarctic Treaty of 1959. 
Before beginning with the development of this paper, it is pertinent to clarify that given the complexity of the Antarctic System and the Antarctic Treaty as its cornerstone this paper will concentrate on the Antarctic Treaty since what is advocated for in said treaty is applicable to the Antarctic System with respect to the material that will be visited below.

\section{THE ANTARCTIC TREATY AND THE PROTECTED LEGAL INTEREST}

\subsection{About the Antarctic Treaty}

The Antarctic Treaty took place during a period of change in the concept of international relations, as a result of a general weariness with war during World War II and individual decisions made by states that led to it. According to the conviction of the day, decisions in international material should be collective and concerted instead of being made individually and based on political force.

Spanier illustrates this change with the following words from former President Roosevelt "(new international relations should) mean the end of a system of unilateral actions, exclusive alliances, spheres of influence, balance of power, and all the other measures that have been attempted throughout the centuries and that have always failed (...) we propose the substitution of all of this for a universal organization in which all the nations lovers of peace will have every possibility to unite" 14 .

Examples of this change are evident in the actions carried out by Albert Einstein who, in 1939, signed a letter to President Roosevelt to ask him to promote a research program on the splitting of the atom and, after World War II, defended a constitution for a "global government" as the only possible guarantee of world peace ${ }^{15}$ or in the proposal of former President Truman with respect to the atomic arsenal and the means for its production that consisted in the United Nations assuming responsibility for its handling ${ }^{16}$.

In this environment of cooperation and multilateralism ${ }^{17}$, the Washington Conference took place between October 15 and December 1, 1959 and the outcome was the Antarctic Treaty that began to take effect in 1961.

It should be recognized that there have been multiple diplomatic initiatives that to a lesser or greater degree have contributed to the creation of the Antarctic Treaty

\footnotetext{
14 Spanier (1991) p. 34.

15 Procacci (2010) p. 321.

16 Gaddis (2008) p. 69.

17 Not without resentments and rivalries for various reasons between those involving themselves in the Cold War that was already in the making. At this time the Cold War was a fact, and the rivalry between the Soviet block and the United States was more than obvious since 1946 when George F. Kennan registered it in his celebrated "long telegram" and in the Foreign Affairs article titled: "Sources of Soviet Conduct", in which the most relevant fragment excesses: "It is evident that the United States cannot wait, in the near future, to enjoy the political intimacy of the Soviet regime. It should continue to consider the Soviet Union as a rival, not a partner, in the political arena. It should continue to expect that Soviet politics do not reflect any abstract of both peace and stability, no real faith in the possibility of a happy, permanent coexistence of the socialist and capitalist worlds, but rather more like a careful, persistent pressure aimed at perturbing and debilitating the influence and power of the rival." Kennan (1991) p. 145.
} 
since James Cook circumnavigated Antarctica on January 17, $1773^{18}$ and the following exploration race and conquest of the Antarctic territory by men such as Amudsen, Scott and Shackleton, among others ${ }^{19}$, until the Treaty came into effect.

For example, Professor Orrego Vicuña ${ }^{20}$ says that in the first half of the 20th century in different international and academic forums three positions about how to approach the topic of Antarctica were posed. The first stance laid out the creation of "an international mechanism to organize cooperation in Antarctica that would be restricted, in general, to the directly involved countries", The second stance "contemplated forms of internationalization based on practical criteria that involved the cooperation of specific fields of activity", and the third position consisted of a "general internationalization of Antarctica, within the scope of the United Nations, or the creation of a special organization",

Parallel to the last position, in 1948, former President Harry Truman gave two proposals about a legal international regime for Antarctica to the seven states ${ }^{21}$ that had laid claims on the territory ${ }^{22}$. The first proposal consisted in putting Antarctica under a trust of the United Nations Organization and the second proposal, that excluded the then Soviet Union, consisted in a limited internationalization of Antarctica by way of a condominium, in which the states that laid claim would have collective sovereignty in accordance with the norms of international public law and the international experience in material dating back to the 12 th century B.C $C^{23}$.

These proposals were unanimously turned down by the states laying claim and Chile suggested an alternative proposal known as "Plan Escudero", in honor of its creator the diplomat and professor Julio Escudero Guzmán. This plan was the foundation for the current Article IV of the Antarctic Treaty and was based on the 1908 statu quo agreements between the European powers and applicable to the Baltic Sea ${ }^{24}$. It consisted in the creation of a system of modus vivendi in which the seven nations that laid claim to territory in the white continent would suspend their claims through a moratorium and would be able to work together in Antarctica without any of them having to abandon their aspirations ${ }^{25}$. This proposal was not accepted for a long time.

In the 50 s of the last century, there were various incidents that showed the growing tension surrounding the Question of Antarctica. Chile, Argentina, and Great Britain started a competition to back their respective claims, which generated considerable friction, such as, the dismantling of the Argentine and Chilean bases on Deception Island

\footnotetext{
18 LÜDECKE (2009) p. 50.

19 Howkins identifies other explorers less known internationally such as Otto Nordenskjold (Sweden), Douglas Mawson (Australia), Jean Baptiste Charcot (France), Nobu Shirase (Japan), Adrien De Gerlache (Belgium), Julián Irizar (Argentina) y Luis Pardo (Chile). See Howkins (2009) p. 3.

20 Orrego (1994) p. 597 et seq.

21 Great Britain (1908), New Zealand (1923), France (1924), Australia (1933), Norway (1939), Chile (1940) and Argentina (1942).

22 Blum (1994) p. 2.

23 On the historical experience relating to the condominium, see SAmuELs (2008) pp. 732-780.

24 Berguño (2009) p. 72.

25 Barros (1990) p. 855.
} 
by the crew of the British ship HMS Snipe by means of bombarding these bases. In addition to this, there was pressure from countries, such as India, that took the Antarctic problem to the General Assembly of the United Nations ${ }^{26}$ and the very own pressures from the intensification of the Cold War.

In this context, the International Geophysical Year played an important role in the management and the creation of the Antarctic Treaty ${ }^{27}$. The International Geophysical Year was a worldwide event on the study of natural phenomenon, sponsored by the United Nations that took place between July 1, 1957 and December 31, 1958.

During a conference to prepare for the International Geophysical Year, it was decided that the two regions that should be explored were Antarctica and outer space. This translated into more interest in Antarctica from many states, particularly those that had territorial claims on the white continent, plus the United States, the former Union of Soviet Socialist Republics, Belgium, Japan, and South Africa, that proceeded to establish 60 winter bases in Antarctica and the islands in the Southern Ocean for research purposes $^{28}$.

While the implementation of the International Geophysical Year helped to diffuse the diplomatic conflicts in the Antarctic territory and prepared a path towards negotiation by way of carrying out scientific activities ${ }^{29}$, in 1958 the United States, through the National Security Council, established in a parallel manner, four objectives of national interest over Antarctica (NSC 5804/1) that made up the North American policy on the white continent:

1. Prevent the use of Antarctica for military purposes.

2. Provide freedom for scientific research.

3. Establish a collective, organized administration on behalf of the directly involved states.

4. Preserve Antarctica for only peaceful purposes ${ }^{30}$.

This is how, with the boost provided by the success of the International Geophysical Year and the establishment of the North American policy on Antarctica, the United States proposed the diplomatic conference that would lead to, not without difficulties ${ }^{31}$, the signing of the Antarctic Treaty on December 1, 1959, which had as its pillars the

\footnotetext{
26 DodDs (2009) p. 34 et seq.

27 The fundamental milestone that made possible the Antarctic Treaty generally is attributed to the role that the International Geophysical Year (1957 and 1958) played, although there were detractors to the importance of the International Geophysical Year in the diplomatic process that led to the creation of the Antarctic Treaty, just as it is stated among others: Becker (2010) p. 3; Dodds (2006) p. 60; Sсотt (2011) p. 52.

28 LinCOLN (1995) p. 4.

29 The cooperation between researchers during the International Geophysical Year led to the formation of the Scientific Committee of Antarctic Research (SCAR), an organization of scientific cooperation.

30 National Security Council (United States). NSC 5804/1, p. 485.

31 On the disputes and difficulties in the diplomatic negotiation, consult among others: Bergin (1988); State Department (1991); Van Der Essen (1996).
} 
previously listed North American objectives and the proposed "Plan Escudero" that is currently Article IV of the treaty ${ }^{32}$.

\subsection{ON THE PROTECTED LEGAL INTEREST}

Considering the complexity of the topic that it regulates, the structure of the Antarctic Treaty is relatively simple. It begins with a preamble in which the signing states ${ }^{33}$ express the importance of Antarctica being used for peaceful purposes, the importance of scientific contributions, and the establishment of scientific bases for cooperation. Following this, 14 articles are included that form the base for the regulation of the current Antarctic System of which the Antarctic Treaty is its cornerstone.

With respect to the legally protected interest, it can be said that it is dual, or to be clearer, there are two legal interests protected by the Antarctic Treaty depending on the activity being carried out there. On one hand, for certain activities the legal interest is the territory that is regulated by the Antarctic Treaty, this is to the south of $60^{\text {th }}$ parallel (Article IV, Antarctic Treaty) and, on the other hand, there are activities where the legally protected interest is the environment in Antarctica.

The reason for this difference rests on the fact that while carrying out activities in which the protected legal interest is the Antarctic territory in its entirety, one cannot physically enter Antarctica to carry out the said activities or, in other words, there is a total prohibition with respect to the Antarctic space. In the second type of activity, one can have a physical presence in the white continent, but cannot affect the environment of Antarctica.

Among the activities where the legally protected interest is the entire Antarctic territory and, therefore, their practice is banned, it can be found:

- Measures of a military character (Article I, A.T.)

- The establishment of military bases and fortifications (Article I, A.T.)

- The carrying out of military maneuvers (Article I, A.T.)

- Tests of all kinds of weapons (Article I, A.T.)

- Acts or activities that assert, support, or deny a claim of territorial sovereignty in Antarctica or those that create rights to sovereignty in this region (Article IV, A.T.)

- Acts in which new claims of territorial sovereignty in Antarctica are made (Article I, A.T.)

- Acts that expand the previous territorial claims (Article IV, A.T.)

- Nuclear explosions (Article V, A.T.)

- Dumping of radioactive waste (Article V, A.T.)

- Activities working against the intentions and principles of the Antarctic Treaty (Article X, A.T.)

\footnotetext{
32 According to Berguño (2009) p. 72, the writing of Article IV was worked on by the Legal Consultant of "Quai d'Orsay", André Gros, and perfected at the Washington Conference.

33 Argentina, Australia, Belgium, Chile, France, Japan, New Zealand, Norway, Union of South Africa (now Republic of South Africa), the former Union of Soviet Socialist Republics, the United Kingdom, North Ireland and the United States of America.
} 
As far as the activities in which the legally protected interest is the Antarctic environment, the following can be found:

- Research and scientific cooperation (Article II, A.T.)

- Employment of military personnel or teams for scientific research or for whatever peaceful purpose (Article I, A.T.)

- Activities of observers (Article VIII, A.T.)

- Expeditions to Antarctica and within Antarctica (Article VII, A.T.)

However, after having seen the analysis of the legally protected interests, we should use as a reference, although be it concise in order not to get away from the objectives of this paper, that the protection and the regulations over the Antarctic territory have continued to be perfected with the development of the Antarctic System, of which the Antarctic Treaty is the first pillar. With this the legal interests and the permitted, limited, or banned activities also have been extended and developed in the other treaties that make up the aforementioned Antarctic System.

It is worth quoting the most relevant examples of the instruments that make up the Antarctic System that follow the logic of Antarctica as a legally protected interest as far as its territory and the Antarctic environment, in which Antarctica is the space that one can use for certain purposes without substantially altering the environment:

- "Agreed Measures for the Protection of Antarctic Flora and Fauna", adopted in Belgium, in 1964, it establishes Antarctica as a "special zone for conservation". Additionally, it establishes a regime for specific protection with respect to certain Antarctic flora and fauna ("Protected Species") and it establishes special zones in the Antarctic territory such as in the case of the "Especially Protected Zones" and "Sites of Special Scientific Interest".

- "Convention for the Conservation of the Antarctic Seals", adopted in London, in 1972 , in which boundaries for catching seal species are established, and catch zones and closed seasons are designated.

- "Convention for the Conservation of Antarctic Living Marine Resources" that was adopted in Canberra, Australia, in 1980, and took effect in 1982. This convention had as its objective the conservation of all Antarctic living marine resources (fish populations, mollusks, crustaceans, and all the other species of living organisms, including birds, with the exception of whales and seals that are included in other previous international agreements). The convention establishes as a measure of conservation "the rational usage" of living resources.

- "Protocol on Environment Protection to the Antarctic Treaty" or the Madrid Protocol, as it is best known since it was adopted in this city in 1991. This protocol establishes that Antarctica is a "natural reserve dedicated to peace and science" and explicitly prohibits whatever type of activity related to Antarctic mineral resources. The protocol has annexes that refer specifically to the following: 
1. Impact evaluation on the environment.

2. Conservation of the Antarctic flora and fauna.

3. Elimination and treatment of residues.

4. Prevention of marine contamination.

5. System of protected areas.

6. Eminent responsibility for environmental emergencies.

\subsection{Principles contained in the Antarctic Treaty}

The Antarctic Treaty (A.T.) contains various principles that are the result of the entire diplomatic process carried out for its creation and of the necessary agreements so that the management of the white continent could be viable. These principles are:

1. Peaceful usage of the Antarctic territory (Article I, A.T.).

2. Research freedom (Article II, A.T.).

3. International Scientific Cooperation and exchange of: (i) information on scientific program projects in Antarctica, (ii) scientific personnel between the expeditions and stations in Antarctica, and (iii) scientific observations and results on Antarctica, which will be freely made available (Article III, A.T.).

4. Suspension of territorial claims, prohibition from making new claims or extending those made while the A.T. was in effect, and absence of sovereignty in the activities carried out in Antarctica (Article IV, A.T.).

Another principle exists that is not specifically declared in the text of the Antarctic Treaty, but that has been fundamental for the sustainability and development of the Antarctic System. This principle is that of consensus in the making of decisions that is concretely seen in the Consultative Meetings (Article IX, A.T.) that will be dealt with further on. There are examples of this principle in some parts of the Antarctic Treaty, such as that established in Article XII of the A.T. with respect to the modification of the same treaty and it is done under the following terms that reveal the mentioned principle: "This Treaty could be modified or amended, at whatever moment, with the unanimous consent of the Contracting Parties (...)",

It cannot be stressed enough that the mentioned principles currently are being put to the test by some of the trends that are being seen in Antarctic activities, such as bioprospecting ${ }^{34}$, the regulating of aquatic subglacial research ${ }^{35}$, tourism, climate change, whale hunting ${ }^{36}$, and the problem of the continental shelf, which is a topic of great importance in the Chilean Antarctic policy ${ }^{37}$ and to which we will dedicate a few sentences.

34 On the difficulties that bioprospecting represents for the Antarctic Treaty, consult among others: VILLAMIZar (2012); Hemmings (2010); Tvedt (2010).

35 On the specific see Scotт (2008).

36 On the specific see International Court of Justice, Australia vs. Japan.

37 On the specific see Gorostegui and Waghorn (2012). 
The problem of the continental shelf is basically a conflict between the provisions of the Antarctic Treaty and the regulations of the United Nations Convention on the Law of Sea of 1982 (UNCLOS). While the Antarctic Treaty and its Article IV establishes that while it is in force "(...) there will be no new claims on territorial sovereignty in Antarctica, nor will previously enforced claims be extended (...)", the UNCLOS in its Article 76 regulates all with respect to the continental shelf and, thus, the coastal states can claim this shelf as part of their territory.

In fact, this claim on the continental shelf has been put before the Commission on the Limits of the Continental Shelf on behalf of various states. The first to do this was Australia in November 2004. Afterwards, New Zealand did it in 2006. Argentina followed in April 2009, as well as Chile ${ }^{38}$, Norway, and the United Kingdom in May 2009 with different degrees of claims. This situation made it so that the Consultative Meeting XXXII that took place in Baltimore, United States, in which the fifteenth anniversary of the Antarctic Treaty was celebrated, a Ministerial Declaration was made: The Consultative Parties came together in "Reaffirming the importance that they grant to the contribution made by the Treaty and, specifically through Article IV, to assure the continuation of international harmony in Antarctica", In any case, despite the attempt to make sure the Antarctic Treaty prevails over the UNCLOS, it is a topic open for discussion ${ }^{39}$.

\section{PROTECTION MECHANISMS OF THE ANTARTIC TERRITORY CONTAINED IN THE ANTARCTIC TREATY}

Given the legally protected interests indicated in the previous section, we proceed now to present the mechanisms set out by the same Antarctic Treaty to protect these legal interests and guarantee the peaceful purposes for which the Antarctic territory should be used. The classification that we present is carried out to achieve a better understanding of that expressed in the treaty since there is no systematization of the mechanisms in this one, but rather a statement in such a manner that, for the person not well-versed in the Antarctic Treaty, the Antarctic protection mechanisms can become a difficult topic to understand.

\subsection{Observers ${ }^{40}$}

Article VII of the Antarctic Treaty establishes this mechanism with "the purpose of promoting the objectives and assuring the use of the regulations" in the treaty and consists in the states that are able to participate in the Consultative Meetings (contemplated in Article IX of the treaty) having the right to designate observers to carry out inspections. In order

\footnotetext{
38 Chile did it as a "Preliminary Information Statement".

39 On the specific see Sсотт (2009).

40 Given the advances in the Antarctic System, there are currently specialized observers according to determined areas of protection. This is the case for the observers of the Commission for the Conservation of Antarctic Living Marine Resources, observers for the Scientific Committee on Antarctic Research (otherwise known as SCAR), observers SCAR in agreement with the Convention for the Conservation of Antarctic Seals, observers of the Council of Managers of Antarctic National Programs.
} 
to make the mechanisms effective, these observers (that are nationals of the Contracting Party that designates them) have the freedom to access at any moment the following:

1. Each and every Antarctic region.

2. All of the stations, installations, and teams that can be found in the Antarctic territory.

3. All of the ships and airplanes at the points of embarkation and disembarkation of personnel or cargo in Antarctica.

4. Carry out aerial observations in any moment in each and every Antarctic region

In order for this mechanism to be effective, the Contracting Parties should report in advanced the following:

1. All expeditions to Antarctica and within Antarctica in which their ships or nationals participate and all expeditions to Antarctica that are organized or begin in their territory

2. All stations in Antarctica staffed by their nationals

3. All personnel or military team that they are planning on bringing to Antarctica

\subsection{National Jurisdiction and Consultations}

This mechanism makes up one of the few events in which the extraterritorial nature of national law operates since, as jurisprudence of the Permanent Court of International Justice reminds us in the well-known Lotus case, "(...) jurisdiction is certainly territorial; it cannot be exerted outside the territory more than under a rule that permits belonging to the customary international law or a convention" 41.

According to Article VIII of the Antarctic Treaty, the designated observers, scientific personnel, and their accompanying personnel members are subject to the jurisdiction of the Contracting Party of which they are nationals, in terms of the actions and omissions that take place while they are in Antarctica with the purpose of fulfilling their duties. In the case of controversy over exercising jurisdiction, a mechanism of Immediate Consultation is sustained with the objective of reaching a mutually acceptable solution.

In other words, given that in accordance with Article IV one cannot exert sovereignty over the Antarctic territory, but it is unacceptable that certain actions or omissions remain unpunished, the mentioned Article VIII divides the form of applicable jurisdiction into people that have privileges and those that do not ${ }^{42}$.

Those that have the privilege of having as applicable jurisdiction that of their nationality are the observers, scientific personnel, and support staff. Those that do not have the privilege of having as jurisdiction that of their nationality are all those that belong to the exceptional personnel or in other words tourists, visitors, etc. In the case

41 France vs. Turkey: Permanent Court of International Justice September 7, 1927 (Lotus Case Sentence). Arret No. 9. 1927, P.C.I.J., series A. no. 10, pp. 16-30.

42 Снатнам (2010) p. 335. 
of the non-privileged, the mechanism to determine the applicable jurisdiction is that of the Consultations, for which one should in principle turn to the custom of international public law in order to define the applicable jurisdiction.

This mechanism of National Jurisdiction and Immediate Consultations are backed by the Consultative Meetings, which will be dealt with further along, but some practical cases that have been presented have revealed serious deficiencies, such as those in the following examples:

- Dr. Rodney Marks was a young Australian astrophysicist that passed away on Antarctic territory on May 12, 2000, during a research expedition. Dr. Marks was employed by the Smithsonian Astrophysical Observatory (SAO) on the AmundsenScott Base that is a North American station in Antarctica. According to North American authorities, Dr. Marks died of natural causes, but when the body arrived in New Zealand and was examined by a forensic doctor it was determined that Marks had a high dose of methanol in his system ${ }^{43}$.

In this case, the United States as well as New Zealand were interested in applying their jurisdiction, the United States as the employer and New Zealand since the event happened in a zone that they declare as their own. As one might expect, the delays in defining the corresponding jurisdiction have affected the investigation and even in 2008, eight years after his death, there was still no cause found for the death of the young astrophysicist.

- In 1981, some customs officials from New Zealand opened and confiscated large quantities of mail from the United States addressed to United States workers residing in Antarctica, after it was discovered that they contained numerous packages of marijuana and other illegal drugs. The police in New Zealand detained and interrogated the addressees upon returning home from Antarctica through New Zealand. After the interrogations, a United States naval officer was tried in court and condemned to jail in New Zealand, while the charges filed against another three United States civilians were thrown out. Neither the United States military authorities nor the federal government pressed charges against these individuals ${ }^{44}$.

\subsection{Consultative Meetings}

According to that establish in Article IX of the Antarctic Treaty, Consultative Meetings take place every year, with the purpose of "(...) exchanging information, mutually seeking advice on matters of common interest related with Antarctica, and formulating, considering, and recommending to the governments measures to promote the principles and objectives of this treaty, including measures related to:

(a) use of Antarctica for exclusively peaceful purposes;

(b) facilities for scientific research in Antarctica;

43 Booker (2008).

44 Chatham (2010) p. 348. 
(c) facilities for international scientific cooperation in Antarctica;

(d) facilities for exercising the rights of inspection expressed in Article VII of this Treaty;

(e) questions related to the exercising of jurisdiction in Antarctica;

(f) protection and conservation of living resources in Antarctica".

The Consultative Meetings are a multidimensional forum that have allowed for the constant advancement of the Antarctic System and which allow for everything from the exchange of points of view to negotiations on binding instruments.

In this order of ideas, the Consultative Meetings are: (i) a political forum since they allow for political dialogue among the states party to the treaty; (ii) a coordination forum because through these meetings reports by the observers to the representatives of the parties are delivered and in this way the Antarctic System can be coordinated (Article IX, number 3, Antarctic Treaty); (iii) a regulation forum because regulatory "measures" are recommended for activities being developed in Antarctic territory ${ }^{45}$.

Regarding the regulatory topic, the so called "measures" taken in the framework of the Consultative Meetings follow a procedure in which, in first place, various members in an informal setting discuss a proposal for a series of recommendations and negotiate their content. Once the text has been agreed upon, the measure is formally presented to the respective Consultative Meeting. In the plenary discussion, the representatives agree by consensus to adopt the measure. The representatives then recommend the approval of the adopted measure to their respective governments. During this third phase, each government decides through its own internal process if they will accept the measure. The final phase is the approval of the measure and its subsequent incorporation in the own legislation of the states parties ${ }^{46}$.

One of the aspects to consider, for the protection of Antarctica, is the degree of obligation of the "measures" recommended in these Consultative Meetings. Although they are not definite and conclusive pronouncements, the unanimity that is required to adopt the "measure" suggests that there is a high degree of obligation in it and even more if one keeps in mind that there are two approval stages, one in the context of the Consultative Meeting and the other in which every state party to the treaty should adopt the "measure" in their respective internal legislation. Thus, if there is rule of law, it is obligatory according to the principle of legality. It is for this reason that we dare to assert along with Joyner ${ }^{47}$ that there is obligation in the "measures" adopted in the Consultative Meetings.

\subsection{Appropriate Efforts and the States Parties}

Another protection mechanism of the Antarctic territory, so that no one carries out any type of activity contrary to the intentions of the Antarctic Treaty, concerns the appropriate efforts of the states, such as that established in Article X of the Antarctic Treaty. These efforts, that should be compatible with the United Nations Charter,

45 On legal validity see: JoYNer (1998).

46 Secretary of the Antarctic Treaty (2011) p. 9 et seq.

47 JOYNer (1998). 
constitute a very powerful mechanism given that the five permanent members of the Security Council of the United Nations are party to the Antarctic Treaty, and if on top of this the quantity of soldiers, population, gross domestic product, among others is added up from the 50 states parties to the treaty it is obvious that the states that are not parties to the Antarctic Treaty are at a great disadvantage in the case that they attempt to change the status quo in Antarctica either individually or collectively.

In addition to diplomatic, economic, and military power that the Antarctic Treaty member states possess, a very serious aspect to consider is the coherence among the members of the Antarctic Treaty in materials concerning the subject matter of Antarctica since, despite the possible internal struggles within the group, the states parties have proven to be accomplices when faced with concerning challenges in the Antarctic System.

Perhaps the most emblematic event of coherence took place during the $40^{\text {th }}$ session of the United Nations General Assembly in 1985 when during this event, within the context of the so-called "Question of Antarctica" 48 , the General Assembly wanted to vote on resolutions against South Africa for the apartheid policies that it had in place. Except for China and Peru, all of the states parties to the Antarctic Treaty announced that they would not participate in the vote. Peru voted for one of the resolutions, but immediately made clear that its vote did not affect the Antarctic System ${ }^{49}$.

When considering that South Africa had been suspended from the United Nations General Assembly, the final text of the resolution on the "Question of Antarctica" in this session deals in a benevolent way with the condemnation of South Africa in the following terms:

\section{"The General Assembly (...) \\ 1. Observes with worry that the apartheid regime in South Africa continues to maintain its condition as Consultative Party to the Antarctic Treaty; \\ 2. Urges the Consultative Parties of the Antarctic Treaty to exclude the racist regime of apartheid in South Africa from participation in Consultative Party meetings as soon as possible;" (ONU, 40/156).}

Of course, the members of the Antarctic System ignored this and other petitions that were made along the same lines in other General Assembly sessions and South Africa continued participating in institutions in the Antarctic System. This shows to a large degree the coherence and power that the Antarctic Treaty members have in order to dare openly to challenge the United Nations General Assembly.

\subsection{Solution for Controversies}

In line with the same logic as the principle of abstaining from the use of power, Article XI of the Antarctic Treaty regulates the mechanisms that should operate in case

48 Name that the General Assembly of the United Nations gives to the topics related to Antarctica.

49 Charney (1996) p. 74. 
of controversy, with which it seeks to maintain the principle that Antarctica is only for peaceful purposes and where harmony should prevail.

Under this framework, in the case that a controversy should arise between two or more Contracting Parties concerning the interpretation or the implementation of the treaty:

"(...) those Contracting Parties shall consult among themselves with a view to having the dispute resolved by negotiation, inquiry, mediation, conciliation, arbitration, judicial settlement, or other peaceful means of their own choice. (...) Any dispute of this character not so resolved shall, with the consent, in each case, of all parties to the dispute, be referred to the International Court of Justice for settlement; but failure to reach agreement on reference to the International Court shall not absolve parties to the dispute from the responsibility of continuing to seek to resolve it by any of the various peaceful means referred to in paragraph 1 of this Article" 50.

\subsection{The Support of Some Non-Governmental Organizations (NGOs)}

Aside from the state mechanisms for protection of the Antarctic territory contemplated in the Antarctic Treaty, non-governmental organizations (NGOs) exist that also contribute in order to avoid bad conditions in Antarctica. Given the large offering of NGOs principally working on environmental topics, we will limit our descriptions to two examples of the role that they can have in protecting the Antarctic territory.

One example is that of the NGO Antarctic and Southern Ocean Coalition (ASOC) that, as indicated in its name, is a coalition of more than 240 members whose objective is "to assure that the environmental and scientific assets without comparison in the Antarctic region are recognized, respected, and protected for all those that work there or visit" 51.

The ASOC regularly attends, in their role as observer, different scientific and technical meetings of the Antarctic Treaty, including the Consultative Meetings of the Antarctic Treaty and the annual meetings of the Commission for the Conservation of Antarctic Marine Living Resources (CCAMLR). Their participation in these instances represents a contribution for the protection of the Antarctic territory since it advises and plays an active role in the environmental polices and the Antarctic fishing.

Of course, other NGOs exist such as the Sea Shepherd Conservation Society whose role in protecting the Antarctic environment is not as institutionalized as the ASOC, but rather has an active role through which it exercises "direct action" 52 practices. One of the most well-known practices of "direct action", but not the only one, is the protection of the whales using tactics that hinder the whaling ships that hunt them and for which the leader of this NGO Paul Watson has had various confrontations with Japanese whalers.

50 Article XI number 1 and 2 Antarctic Treaty.

51 http://www.cedepesca.net/detalle-articulo-revista.php?id=4 (accessed November 13rd, 2012).

52 http://www.seashepherd.org/espanol/espanol.html (accessed November 13rd, 2012). 


\title{
4. THE INTERNATIONAL CUSTOM AS MECHANISM FOR ANTARCTIC PROTECTION
}

The mechanisms laid out in the Antarctic Treaty, with their handicaps, have been successful in protecting the white continent, but according to the principle of law pacta tertiis nec nocent nec prosunt, these mechanisms are only applicable to the states that are party to this treaty and are not applicable to more than 140 states on the planet that are party to the United Nations Organization, but that have not signed the Antarctic Treaty.

Therefore, it is valid to ask: What would happen if some state that is not party is unaware of the provisions in the Antarctic Treaty, or if a state party to the treaty denounces it and subsequently claims to not recognize the institutionality of Antarctica? ${ }^{53}$ Can something be done to this non-party state or the one that has denounced the treaty that is going against the rulings of the Antarctic Treaty, specifically the principles over the peaceful usage of Antarctica, by way of some legal mechanism of international law?

In order to give an adequate response to these questions, we consider that one of the mechanisms that makes possible the enforcement of the Antarctic Treaty over third party states is international custom. This position consists in asserting that the Antarctic Treaty, particularly the usage of the Antarctic territory for peaceful purposes, has created uniform and obligatory practices in a way that would have the same effect as international custom and, therefore, would be binding under this perspective for those third party non-party states.

In order to proceed in putting forward the argumentation, according to which the principles of the Antarctic Treaty have been established as custom of international law, we will first deal with what makes up the custom of international law and, subsequently, the policy between custom and treaty will be analyzed.

We begin by establishing what is custom in international law: the majority of scholars in international law refer to Article 38 in the Statutes of the International Court of Justice ${ }^{54}$ when they analyze the sources of international law. This article provides the following:

\begin{abstract}
"Article 38
The Court whose function is to decide in accordance with international law such disputes that are submitted to it, shall apply:

international conventions, whether general or particular, establishing rules expressly recognized by the contesting states;

international custom, as evidence of a general practice accepted as law;

the general principles of law recognized by civilized nations;

subject to the provisions of Article 59, judicial decisions and the teachings of the most highly qualified publicists of the various nations, as subsidiary means for the determination of rules of law.
\end{abstract}

\footnotetext{
53 On the legal possibilities of denouncing the Antarctic Treaty the general arguments on denouncing any treaty are valid and carried out by: Brilmayer and Tesfalidet (2011); Dodge (2010).

54 Among others: Jiménez de Aréchaga (1980) p. 17 et seq; Pellet (2006) p. 749 et seq; Verdross (1967) p. 14 et seq and 89 et seq.
} 
This provision shall not prejudice the power of the Court to decide a case en aequo et bono, if the parties agree thereto",

The literal meaning of $\mathrm{b}$. in the article under consideration establishes that in order to define a conduct as a custom of international law, it should be "a general practice accepted by law" of which two elements emanate: on one hand, there is an external or physical element that is a reiterated or common practice ${ }^{55}$ and, on the other hand, there should exist a psychological element, opinio juris sive necessitatis or simply opinio juris, that consists in the conviction among the states that this determined type of conduct is demanded by international law ${ }^{56}$, namely that it is a obligatory practice.

Therefore, the International Court of Justice in the case of the North Sea Continental Shelf Cases determined that:

"Not only must the acts concerned amount to a settled practice, but they must also be such, or be carried out in such a way, as to be evidence of a belief that this practice is rendered obligatory by the existence of a rule of law requiring it. The need for such a belief, i.e., the existence of a subjective element, is implicit in the very notion of the opinio juris sive necessitatis. The States concerned must therefore feel that they are conforming to what amounts to a legal obligation" 57.

Having reviewed that concerning to what is custom in international law, and the elements that it requires to consolidate itself as such, it is important to address how the Antarctic Treaty can be converted into a custom of international law.

Following the author Eduardo Jiménez de Aréchaga, the interrelation between custom and the treaties can be found by way of that which this author calls "effects". In this regard, there are three types of effects, which are known as: (i) the declarative effect, (ii) the crystallizer effect and (iii) the constituent or generator effect ${ }^{58}$.

The declarative effect consists in that a preexistent custom is declared or enunciated in a treaty in such a way that the existence of the treaty is proof of the custom, even if the treaty has not taken effect ${ }^{59}$. We consider it difficult for the Antarctic Treaty to fit into this type of effect given that previous to the formation of the treaty no custom existed with respect to the Antarctic territory, but rather the contrary for there had been a constant dispute and a number of authors that kept world peace and security at unease, which was succinctly related when dealing with the formation of the Antarctic Treaty. Based on the above, this effect could not be useful when arguing that the Antarctic Treaty had created international custom. This is the reason for which we will analyze the other effects.

55 Rousseau (1961) p. 59.

56 Monroy Cabra (1998) p. 73 et seq. Akehurst (1994) p. 36.

57 Federal Republic of Germany vs. Denmark; Federal Republic of Germany vs. Netherlands: International Court of Justice February 20, 1969 (North Sea Continental Shelf Cases Sentence), Recueil, 1969, p. 44.

58 Jiménez de Aréchaga (1980) p. 19 et seq.

59 Díez de Velasco (2004) p. 130. 
The crystallizer effect assumes that there is a custom that crystallizes ${ }^{60}$ a customary rule through the adoption of a treaty. In the words of Díez de Velasco this effect "is distinct because of the existence of a customary rule in the formation process that achieves being formally crystallized under a sufficiently relevant act, whether it be -common assumption- the adoption of a multilateral treaty that gathers the same content of objective conduct as the customary practice previous to the treaty, including any proof, or demonstration of its general acceptance by the participating States in an encoding process, although this acceptance does not have legal standing, always when the previous practice is so constant and uniform as to facilitate the crystallization of a consensus on its legal concrete content already embodied in this practice" 61 .

This effect covers up certain problems in order for it to be applicable to the Antarctic Treaty. On one hand, it requires a customary practice previous to the treaty, a practice that did not exist before the Washington Convention in 1959, from which was born the Antarctic Treaty, except with regard to research freedom that was instituted in the International Geophysical Year (1957-1958). Except for a brief period between one event and another (less than three years), it is not easy to assert that research freedom already had been constituted as a customary practice for the Antarctic case, motive for which in a concrete case it could provide evidence that the treaty does not "effectively gather the customary Law" 62 .

With regard to the usage of the Antarctic territory for peaceful purposes, the situation is similar to that of the cases on freedom of scientific research since the precedents are not sufficient in the past and what had happened before the Antarctic Treaty was a fight to ensure territorial claims, as has already been mentioned. Perhaps, the most convincing demonstration of the peaceful usage of the Antarctic territory previous to the Washington Conference was that carried out by India en the United Nations General Assembly in 1956, however, is far from earning the title of having generated custom. This pronouncement expressed the following:

"Antarctica, a region that spans more than six million square miles of territory, has a considerable strategic, climatic, and geophysical importance for the world as a whole. With the development of faster communication channels, the area will soon hold a key position of importance in the well-being and progress of nations. The natural wealth of its territorial mass is believed to be considerable and its coastal zones contain important sources of food (...) The Government of India considers that in order to strengthen universal peace, it would be appropriate and timely for all nations to agree and assert that the area will be used as a whole for peaceful means and for the general wellbeing"63.

\footnotetext{
60 "To crystallize" is understood in international law as the act in which a custom takes on an obligatory character. On the specifics, consult among others: VilLiger (1985) pp. 36-37.

61 Diez De Velasco (2004) p. 131.

62 Akehurst (1994) p. 34.

63 DodDs (1997) p. 138.
} 
On the other hand, the crystallizer effect loses its effectiveness in the presence of the persistent objector figure, a figure that appears when a state clearly and consistently demonstrates its opposition to a ruling of customary international law from its creation, in this way avoiding the binding universal effect ${ }^{64}$. In the concrete case of the Antarctic Treaty, it is enough to remember that this took place precisely because there was no agreement about the way in which the Antarctic territory should be used and, accordingly, we dare to assert that the conduct of the states that struggled for this territory was an expressed objection ${ }^{65}$ that contradicted the principles of its peaceful usage. Evidence of this is clearly stated by Dodds in the following terms in the case of Chile, Argentina, and Great Britain:

"Argentina, Great Britain, and Chile were buried in a diplomatic and physical competition for the Antarctic Peninsula (in the 50s of last century). The three countries occupied themselves creating more and more research stations and sought to marginalize the presences of others by destroying any evidence of previous occupation and by producing increasingly more detailed maps of their respective territories" 66 .

Given the above, we consider that it is not viable to assert that the Antarctic Treaty, mainly regarding its peaceful usage, could be considered as a crystallizer for rulings of customary law since, given the events previous to the signing of this treaty, there were no legal elements to think possible the emergence of a custom being crystallized through the treaty.

With respect to the constituent or generator effect, Jiménez de Aréchaga states that this comes from the formation of a custom starting from a ruling in a treaty and thanks to a constant and uniform subsequent practice by the states conforming to that established in the treaty ${ }^{67}$.

We consider that with the Antarctic Treaty a constant and uniform practice has been progressively created with regard to the peaceful usage of the Antarctic territory without sovereignty, while, in turn, creating respect for the freedom of scientific investigation. This assertion is sustained in that the Antarctic Treaty has remained untouched since its creation, despite its Article XII authorizing modifications under certain conditions. Given that it has not been modified and even the subsequent treaties that form part of the Antarctic System (such as the Madrid Protocol in 1991) recognize that they do not modify it, the practices based on the Antarctic Treaty are uniform, especially in the case of the peaceful usage of the Antarctic territory.

64 Currie (2008) p. 44.

65 This position is sustained by the argumentation of Patrick Dumberry and according to his arguments the relevant part in order to exert an objection is not the form, but rather the intention of the state to oppose the emerging custom, in such a way that the objection can materialize by any means. On the specifics, see DumbERRY (2010) p. 781.

66 DodDs (2009) p. 37.

67 Jiménez De Aréchaga (1980) p. 23 et seq. 
The big problem that could be pointed out with respect to this effect, in order to determine if there is international custom, concerns whether or not the general practice created by the Antarctic Treaty is accepted as law or, in other words, if the practice of using the Antarctic territory for peaceful purposes has opinio juris sive necessitatis ${ }^{68}$. In order to determine this psychological character of obligation of peaceful usage of Antarctica, we consider the most useful test to be the treatment that has been given to the "Question of Antarctica" in the General Assembly of the United Nations, especially that expressed in the resolutions on this topic.

The former has its foundation because, in addition to the possible generator effect of custom in international law that could be attributed to the Antarctic Treaty, which could be questionable ${ }^{69}$, the resolutions of the General Assembly of the United Nations can constitute proof of customary law, according to a majority of authors ${ }^{70}$.

Therefore, the Committee on the Formation of Customary Law of the International Law Association ${ }^{71}$ gives a fundamental importance to the resolutions of the General Assembly for the formation of international custom as there is a large amount of political content in these UN resolutions. Not only are the developed states represented, but also the developing states and those recently made independent or created, in such a way that having approved the resolutions these states cannot claim that they are persistent objectors, nor that in their arriving later, in this case to the Antarctic Treaty, they could not make some objection or find fault.

In addition to the doctrinal positions that give validity of opinio juris to the resolutions of the General Assembly at the UN, the International Court of Justice accordingly declared in their Advisory Opinion on July 8, 1996 about the legality of the threat or usage of nuclear weapons in the following way:

"The resolutions of the General Assembly, although they are not binding, can sometimes set the standards. In certain circumstances, they can provide important evidence to establish the existence of a rule or the rise of an opinio juris. In order to determine if this is true of a given resolution of the General Assembly, it is necessary to keep in mind its content and the conditions for its adoption, and it is also necessary to see if an opinio juris exists with respect to its regulatory character. A series of resolutions can show the gradual evolution of the opinio juris necessary for establishing a new rule"72.

Taking shelter in the doctrinal positions exposed on the formation of custom starting with the resolutions of the General Assembly of the UN and the Advisory Opinion

\footnotetext{
68 Jiménez De Aréchaga (1980) p. 28 et seq.

69 Although some professionals state that it has been built up as ius cogens. On the specifics, see. BerGUÑo (2009) p. 81.

70 On the specifics, see. Figueroa (1991) p. 107.

71 Iinternational Law Association (2000) p. 3.

72 Advisory Opinion on the legality of the threat or use of the nuclear weapons: International Court of Justice July 8, 1996, Justice Reports, Advisory Opinions and Orders, pp. 254-255.
} 
of the International Court of Justice, it is necessary to analyze what has been the treatment of the so-called "Question of Antarctica" in the General Assembly of the United Nations.

While pronouncements have existed about the Question of Antarctica in the General Assembly of the UN since the 50s of the last century, such as the one made by India in 1956 , since the $38^{\text {th }}$ period of sessions that this institution celebrated in 1983 , they have dealt with the topic on 16 different opportunities, the last in 2005. In the resolutions that have come from these sessions the assertion (or reassertion) of the peaceful usage of the Antarctic territory, the recognition of the Antarctic Treaty, and the importance of the Antarctic System have all been reiterated. The expressions that generally are used in this regard are the following:

- "Reaffirming its conviction that, in the interest of all humanity, Antarctica should continue to be used exclusively for peaceful means and not as the setting nor the object of international disagreements".

- "Recognizing that the Antarctic Treaty, in which is stipulated, among other things, the demilitarization of the continent, the probibition of nuclear explosives and the elimination of nuclear waste, the freedom of scientific research, and the free exchange of scientific data, promotes the intentions and principles of the Charter".

- "Bearing in mind the Antarctic Treaty and the importance of the system derived from it",

We consider that the constant and uniform reiteration that the resolutions of the General Assembly of the UN make on the peaceful usage of the Antarctic territory, such as the recognition of the Antarctic Treaty and the system coming out of it, is convincing proof of the obligatory character that should be maintained in the international arena with respect to Antarctica. In the resolutions the psychological element of the custom of international law, in other words opinio juris, is present and, if added that it is a general practice, then we believe that all the requirements exist to argue that there is international custom. Therefore, a state that is not party to the Antarctic Treaty should respect the principles established in it, mainly that concerning the peaceful usage of the Antarctic territory.

Additionally, if a state that is not party to the Antarctic Treaty and that has voted on some or all of the resolutions on the Question of Antarctica should be unaware of the mentioned principles, we believe that it is possible to put into practice the North American law figure that has been incorporated in the international law of Estoppel, according to which a "person (in this case a state) cannot be allowed to deny a state of truth that they have established as the truth, expressly through words or implicitly through their conduct..."73.

73 Díez- Picazo y Ponce de León (1963) p. 62. 
Table 1

List of resolutions in which the peaceful usage of antartica and the antartic treaty are recognized

\begin{tabular}{|c|c|c|c|c|}
\hline $\begin{array}{c}\text { General assembly } \\
\text { session }\end{array}$ & Year & Resolution & $\begin{array}{c}\text { Affirmation of peaceful } \\
\text { usage of Antarctica }\end{array}$ & $\begin{array}{l}\text { Reference or recognition } \\
\text { of the Antarctic treaty }\end{array}$ \\
\hline 38 & 1983 & $38 / 77$ & $X$ & \\
\hline 39 & 1984 & $39 / 152$ & $\mathrm{X}$ & $\mathrm{X}$ \\
\hline 40 & 1985 & $40 / 156$ & $\mathrm{X}$ & $\mathrm{X}$ \\
\hline 41 & 1986 & $41 / 88$ & $\mathrm{X}$ & $\mathrm{X}$ \\
\hline 42 & 1987 & $42 / 46$ & $\mathrm{X}$ & $\mathrm{X}$ \\
\hline 43 & 1988 & $43 / 86$ & $\mathrm{X}$ & $X$ \\
\hline 44 & 1989 & $44 / 124$ & $\mathrm{X}$ & $\mathrm{X}$ \\
\hline 45 & 1990 & $45 / 78$ & $\mathrm{X}$ & $X$ \\
\hline 46 & 1991 & $46 / 41$ & $\mathrm{X}$ & $\mathrm{X}$ \\
\hline 47 & 1992 & $47 / 57$ & $\mathrm{X}$ & $\mathrm{X}$ \\
\hline 48 & 1993 & $48 / 80$ & $\mathrm{X}$ & $\mathrm{X}$ \\
\hline 49 & 1994 & $49 / 80$ & $\mathrm{X}$ & $\mathrm{X}$ \\
\hline 51 & 1996 & $51 / 56$ & $\mathrm{X}$ & $\mathrm{X}$ \\
\hline 54 & 1999 & $54 / 45$ & $\mathrm{X}$ & $\mathrm{X}$ \\
\hline 57 & 2002 & $57 / 51$ & $\mathrm{X}$ & $\mathrm{X}$ \\
\hline 60 & 2005 & $60 / 47$ & $\mathrm{X}$ & $\mathrm{X}$ \\
\hline
\end{tabular}

Prepared by the author based on the resolutions of the General Assembly of the United Nations Organization

Therefore, a state that has already accepted in a reiterative manner the principles of the Antarctic Treaty cannot in a subsequent act deny these principles, such as has been recognized on various occasions by the International Court of Justice ${ }^{74}$, among others in the case related to award issued by the king of Spain on December 23, 1906, that set the following tone:

"(...) considering that Nicaragua freely accepted the appointment of the king of Spain as arbitrator; that Nicaragua did not express any objection to the legal authorities of the king of Spain, his appointment as arbitrator is already based on irregularities, due to the termination of the Gámez-Bonilla Treaty before the king of Spain could declare the acceptance of his duties as arbitrator; and that Nicaragua acted fully as part of the arbitration proceedings before the king, the Court considers that this country cannot appeal either one of both motives as reason for invalidity of the ruling (...)

In the opinion of the Court, Nicaragua, through its expressed statements and by its behavior, recognized the validity of the award and now cannot return this recognition to appeal the validity of the award. The fact that Nicaragua had not expressed any doubt

74 One can consult among other the following sentence: Australia vs. France: International Court of Justice December 20, 1974 (Nuclear Tests Sentence) I.C.J. Reports 1974, pp. 259-270. 
with respect to the validity of the award until various years passed after having had knowledge of the award text confirms the conclusion to which the Court as reached"75.

In conclusion, the resolutions of the United Nations Organization on the "Question of Antarctica" are evidence of uniformity of the practice of peaceful usage of the Antarctic territory, in terms of the constant reiteration and in the same literal tone as the resolutions, and of the opinio juris of the established principles of the Antarctic Treaty. Even if one accepts a certain doctrinal sector, these resolutions can be considered the source in itself of international custom ${ }^{76}$, although it can be criticized that Article 38 of the Statute of the International Court of Justice does not make reference to the resolutions as sources of international law so that the Court decides ${ }^{77}$.

\section{CONCLUSIONS}

Throughout this paper, one has been able to observe that the Antarctic Treaty has some mechanisms that have been successful in protecting the Antarctic territory and so that it is used for peaceful purposes, although some of these mechanisms can be criticized or have some flaws. The research problem that it was attempting to solve concerned the legal situation in the case that the own mechanisms of the mentioned treaty should fail in protecting its legally protected interests, concretely if it could be argued that the principles in the Antarctic Treaty have constituted custom in international public law and, therefore, it is source of valid law against third party states that are not party to the Antarctic Treaty.

After carrying out an analysis, we consider that in the given case that a third party state not party to the Antarctic Treaty is unaware of the principle of peaceful usage of Antarctica, it is possible to argue that this principle has constituted custom in international law and, therefore, valid against states that eventually denounce the Antarctic Treaty or that do not take part in it, position in which the Antarctic territory will be protected against a non-peaceful usage.

However, in the eventuality that a state not party to the Antarctic Treaty infringes upon the principles contained in it, the states parties to it would be those to employ, using a controversy resolution mechanism of their choice, the international custom constituted by the Antarctic Treaty. In international law the burden of proof, onus probandi, rests with those who argue for the practice that is supposedly custom, such as that established by the International Court of Justice in the "Right to Asylum Case" between Colombia and Peru, in which it expressed that the "party that invokes a custom of this nature should prove that it has been constituted in such a way that it has been made obligatory for the other party"78.

\footnotetext{
75 Honduras vs. Nicaragua: International Court of Justice November 18, 1960 (Affaire de la sentence arbitrale rendue par le roi d'Espagne le décembre 1906 Sentence) Recueil 1960, p. 213.

76 Díez Velasco (2004) p. 133 et seq and Jiménez de Aréchaga (1980) p. 38 et seq.

77 Pellet (2006) p. 711 et seq.

78 Colombia vs. Peru: International Court of Justice November 20, 1950 (Right to Asylum Sentence) in: I.C.J. Recueil 1950, p. 276.
} 
We consider that the states parties to the Antarctic Treaty and the Antarctic System should start a strong diplomatic campaign with the purpose of getting a large number of states to become parties to the treaty, given that this is an open treaty according to its Article XIII stating that anyone can join. If the number of states parties grows, the system would have more legitimacy and strength in the case of attacks on the guiding principles of the Antarctic System, independent of the fact that until now that the Antarctic protection mechanisms expressed in the Antarctic Treaty have been successful and that one can validly argue that it makes up an international custom with respect to the treaty to make its principles valid against third party states not party to the Antarctic Treaty.

\section{BIBLIOGRAPHY}

Akehurst, Michael (1994): Introducción al Derecho Internacional (Spain, Alianza Editorial).

Barros Van Buren, Mario (1990): Historia Diplomática de Chile (1541-1938). Second edition (Current as of 1958). (Santiago, Editorial Andrés Bello).

Becker, F.W.G. (2010): "Some Reflections on the Antarctic Treaty", The Polar Record (Vol. 46, No. 236, Issue No. 1), pp. 2-4.

Bergin, Patrick T (1988): "Antarctica, the Antarctic Treaty Regime, and Legal and Geopolitical Implications of natural resource exploration and exploitation", Florida International Law Journal (Fall, 1988), pp. 2-50.

Berguño, Jorge (2009): "Evolución y perspectivas del Sistema Antártico", ISTOR, Revista Internacional de Historia (Winter 2009. Vol. 10. Issue 39), pp. 70-84.

Blum, Jonathan (1994): "The deep freeze: Torts, Choice of Law, and the Antarctic Treaty Regime", Emory International Law Review (Fall, 1994), pp. 1-22.

Booker, Jarrod (2008): NZ probe into death hits icy wall. In http://www.nzherald.co.nz/nz/ news/article.cfm?c_id=1\&objectid=10534046. Accessed April 20, 2012.

Brilmayer, Lea and Tesfalidet, Isaias Yemane (2011): "Treaty Denunciation and "Withdrawal" from Customary International Law: An Erroneous Analogy with Dangerous Consequences", in The Yale Law Journal Online 217. (Accessed April 11, 2012). Available at: http://yalelawjournal.org/the-yale-law-journal-pocket-part/ international-law/treaty-denunciation-and-\%22 withdrawal $\% 22$-from-customaryinternational-law:-an-erroneous-analogy-with-dangerous-consequences/

Carré De Malberg, R.(2000): Teoría del Estado - Second edition in Spanish, first reprint. (México, Facultad de Derecho - UNAM - Fondo de Cultura Económica).

Casanovas, Oriol and Rodrigo, Ángel J. (2005): Casos y textos de Derecho Internacional Público. Fifth edition. (Madrid, Editorial Tecnos).

Chatham, Todd F. (2010): "Criminal Jurisdiction in Antarctica: A proposal for dealing with jurisdictional uncertainty and lack of effective enforcement", Emory International Law Review (Vol. 24 (1)) pp. 331-356.

Charney, Jonathan I. (1996): "The Antarctic System and Customary International Law", in Francesco Francioni and Tullio Scovazzi (Eds). International Law for Antarctica. 
Second Edition, (The Hague, The Netherlands, Kluwer Law International) pp. 51102.

Currie, John H. (2008): Public International Law (Canada, Irwin Law).

Díez-Picazo y Ponce de León, Luis (1963): La doctrina de los actos propios (Barcelona, Bosch).

Díez de Velasco, Manuel (2004): Instituciones de Derecho Internacional Público. Fourteenth edition. Reprint, (Madrid, Editorial Tecnos).

Dodds, Klaus (1997): Geopolitics in Antarctica: Views from the Southern Oceanic Rim (Chichester, John Wiley).

Dodds, Klaus (2006): "Post-colonial Antarctica: An Emerging Engagement", Polar Record (Vol. 42, No. 220. Issue 1), pp. 59-70.

DodDs, Klaus (2009): "La administración del continente polar: los orígenes geopolíticos del Tratado Antártico de 1959”, ISTOR, Revista Internacional de Historia (Winter 2009. Vol. 10. Issue 39), pp. 27-49.

Dodge, William S. (2010): "Withdrawing from Customary Law: Some Lessons from History", The Yale Law Journal Online 169. (Accessed April 15, 2012). Available at: http://yalelawjournal.org/images/pdfs/920.pdf

Domingo, Rafael (2010): The New Global Law (United States of America, Cambridge University Press).

Dumberry, Patrick (2010): "Incoherent and Ineffective: The Concept of Persistent Objector Revisited", International and Comparative Law Quarterly. (Vol 59. July 2010), pp. 779-802.

Figueroa Pla, Uldaricio (1991): Organismos Internacionales (Santiago, Editorial Jurídica de Chile).

Gaddis, John Lewis (2008): La Guerra Fría (Barcelona, RBA Libros).

Gorostegui, José Javier and Waghorn, Rodrigo (2012): Chile en la Antártica. Nuevos Desafios y Perspectivas. (Chile, Masters in Foreign Policy, University of Santiago and Association of Career Diplomats, Minitry of Foreign Affairs).

Heller, Hermann (1965): La Soberanía. Contribución a la Teoría del Derecho Estatal y del Derecho Internacional (México, Universidad Nacional Autónoma de México).

Hemmings, Alan D. (2009): "Does bioprospecting risk moral hazard for science in the Antarctic Treaty System?”, Ethics in Science and Environmental Politics (Vol. 10, 2010), pp. 5-12.

Herdegen, Matthias (2005): Derecho Internacional Público (México, Universidad Nacional Autónoma de México. Fundación Konrad Adenauer).

Howkins, Adrian (2009): "Más allá del heroísmo: la historia antártica bajo las sombras de Amundsen, Scott y Shackleton", ISTOR, Revista Internacional de Historia. (Winter 2009. Vol. 10. Issue 39), pp. 3-26.

International Law Association (2000): Committee on formation of customary (General) International Law. Final Report of the Committee. Statement of Principles Applicable to the formation of General Customary Law (London).

Jellinek, Georg (1970): Teoría General del Estado (Argentina, Editorial Albatros). 
Jiménez de Aréchaga, Eduardo (1980): El Derecho Internacional Contemporáneo (Madrid, Editorial Tecnos).

Joyner, Christopher C. (1998): "Recommended Measures Under the Antarctic Treaty: Hardening with Soft International Law”, Michigan Journal of International Law (Vol. 19.) pp. 401-409.

Joyner, Christopher C. (2011): "United States foreign policy interests in the Antarctic", in The Polar Journal (1:1) pp. 17-35.

Kennan, George F. (1991): Las Fuentes de la Conducta Soviética y otros escritos (Argentina, Grupo Editor Latinoamericano).

L'Huillier, Jean (1950): Éléments de Droit International Public (Paris, Éditions Rousseau et $\mathrm{Cie})$.

Lincoln , Paul (1995): "Protecting the white continent: is the Antarctic Protocol mere words or real action?”, Arizona Journal of International \& Comparative Law, (Spring, 1995) pp. 1-27.

Lowe, Vaughan (2007): International Law. (New York, Oxford University Press).

LuARD, Evan (1984): "Who Owns the Antarctic?", Foreign Affairs (Vol. 62, No 5, Summer 1984).

LÜdecke, Cornelia (2009): "Exploración científica en la Antártida: ejemplos desde la época histórica hasta la fecha", ISTOR, Revista Internacional de Historia (Winter 2009, Vol. 10. Issue 39), pp. 50-69.

Monroy Cabra, Marco Gerardo (1998): Derecho Internacional Público. Fourth edition. (Bogotá, Editorial Temis).

Oppenheim, Lassa (1955): International Law I. 8th ed. (London, Hersch, Lauterpacht, Longmans, Green \& Co.).

Orrego Vicuña, Francisco (1994): Derecho Internacional de la Antártida (Chile, Dolmen Ediciones).

Pellet, Alain (2006): "Article 38", in A.A.V.V. Andreas Zummermann, Christian Tomuschat, Karin Oellers-Frahm (Eds.) The Statute of the International Court of Justice. A Commentary (New York, Oxford University Press Inc.).

Pinochet de la Barra, Óscar (1944): "La Antártida Chilena o Territorio Chileno Antártico" (Santiago de Chile, Thesis to achieve degree in the Department of Legal and Social Sciences at the University of Chile).

Procacci, Giuliano (2010): Historia general del siglo XX. Third printing of the first edition in Serie Mayor paperback (España, Editorial Crítica).

Rousseau, Charles (1961): Derecho Internacional Público. (Barcelona, Ediciones Ariel).

Samuels, Joel H. (2008): "Condominium arrangements in international practice: reviving an abandoned concept of boundary dispute resolution", Michigan Journal of International Law (Summer 2008, 727), pp. 732-780.

Scotт, Karen N. (2008): "Regulating Subglacial Aquatic Research under the Antarctic Treaty System”, New Zealand Universities Law Review (23), pp. 134-159.

Scotт, Karen (2003): "Institutional developments within the Antarctic Treaty System", International \& Comparative Law Quarterly (52(2)), pp. 473-487. 
Scott, Karen. (2009): Managing Sovereignty and Jurisdictional Disputes in the Antarctic. Durham University, Durham, UK: The State of Sovereignty: 20th anniversary conference of the International Boundaries Research Unit, 1-3 Apr 2009.

Scotт, Shirley V. (2011): "Ingenious and innocuous? Article IV of the Antarctic Treaty as imperialism", The Polar Journal (1:1), pp. 51-62

Secretaría del Tratado Antártico (2011): Compilación de documentos fundamentales del sistema del Tratado Antártico (Buenos Aires, Secretaría del Tratado Antártico).

Shaw, Malcolm N. (2010): International Law. Sixth Edition, third printing (New York, Cambridge University Press).

Spanier, John (1991): La Política Exterior norteamericana a partir de la Segunda Guerra Mundial (Argentina, Grupo Editorial Latinoamericano).

State Department (1991): Foreign Relations of the United States, 1958-1960, Volume II: United Nations and General International Matter (United States, State Department).

Tvedt, Morten (2010): "Patent law and bioprospecting in Antarctica", Polar Record (doi: 10.1017/S0032247410000045), pp. 1-10.

VAN DER EsSEn, Alfred (1996): “The origin of the Antarctic System”, in Francesco Francioni and Tullio Scovazzi (Eds). International Law for Antarctica. Second Edition, (The Hague, The Netherlands, Kluwer Law International) pp. 17 -30.

Vargas Carreño, Edmundo (2007): Derecho Internacional Público de acuerdo a las normas que rigen en el siglo XXI (Chile, Editorial Jurídica de Chile).

Verdross, Alfred (1967): Derecho Internacional Público. Fifth edition (Madrid, Aguilar S. A. de Ediciones).

Villamizar, Fernando (2012): "El tratamiento doctrinal de la bioprospección como desafío al Derecho Antártico". Lecture presented at the XLII Jornadas de Derecho Público, celebrated at the Pontifical Catholic University of Valparaiso, Chile. Available at: http://www.jornadasdederechopublico2012.pucv.cl/recibidos/Villamizar.pdf

VIlliger M. E. (1985): Customary International Law and Treaties (The Hague, Kluwer).

\section{LEGAL RULINGS CITED}

Convention for the Conservation of Antarctic Seals, 1972.

Convention for the Conservation of Antarctic Living Marine Resources, 1980.

National Security Council (United States), NSC 5804/1, 1958.

Agreed Measures for the Protection of Antarctic Flora and Fauna, 1964.

Protocol on Environmental Protection to the Antarctic Treaty, 1991.

Antarctic Treaty, 1959.

\section{GENERAL ASSEMBLY OF THE UNITED NATIONS RESOLUTIONS CITED}

United Nations Organization, General Assembly Resolution 38/77, 1983.

United Nations Organization, General Assembly Resolution 39/152, 1984

United Nations Organization, General Assembly Resolution 40/156, 1985.

United Nations Organization, General Assembly Resolution 41/88, 1986. 
United Nations Organization, General Assembly Resolution 42/46, 1987.

United Nations Organization, General Assembly Resolution 43/86, 1988.

United Nations Organization, General Assembly Resolution 44/124, 1989.

United Nations Organization, General Assembly Resolution 45/78, 1990.

United Nations Organization, General Assembly Resolution 46/41, 1991.

United Nations Organization, General Assembly Resolution 47/57, 1992.

United Nations Organization, General Assembly Resolution 48/80, 1993.

United Nations Organization, General Assembly Resolution 49/80, 1994.

United Nations Organization, General Assembly Resolution 51/56, 1996.

United Nations Organization, General Assembly Resolution 54/45, 1999.

United Nations Organization, General Assembly Resolution 57/51, 2002.

United Nations Organization, General Assembly Resolution 60/47, 2005.

\section{JURISPRUDENCE CITED}

Australia vs. France: International Court of Justice December 20, 1974 (Nuclear Tests Case) I.C.J. Reports 1974, pp. 259-270.

Colombia vs. Peru: International Court of Justice November 20, 1950 (Asylum Case) I.C.J. Recueil 1950, pp. 265-388.

Denmark vs. Norway: Permanent Court of International Justice April 5, 1933 (Statute Juridique du Groenland Oriental Case), Arret, 1933. P.C.I.J. series A/B, No 53, pp. 36-71.

France vs. Turkey: Permanent Court of International Justice September 7, 1927 (Lotus Case Sentence). Arret No. 9. 1927, P.C.I.J, series A. No 10, pp. 16-30.

Honduras vs. Nicaragua: International Court of Justice November 18, 1960 (Affaire de la sentence arbitrale rendue par le roi d'Espagne le décembre 1906 Sentence) Recueil 1960, pp. 209-214.

Federal Republic of Germany vs. Denmark; Federal Republic of Germany vs. Netherlands: International Court of Justice February 20, 1969 (North Sea Continental Shelf Cases Sentence) Recueil, 1969, pp. 24-46.

United States vs. Holland: Permanent Court of Arbitration 1928 (Judge Max HUBER, La Palma Island Case) Rec. Sent. Arbitral. U.N., vol. II.

Advisory Opinion on the legality of the threat or use of nuclear weapons: International Court of Justice July 8, 1996, Reports on Justice, Advisory Opinions and Orders, pp. 226-313. Official citation: Legality of the Threat or Use of Nuclear Weapons, Advisory Opinion, I.C.J. Reports 1996, p. 226.

\section{RESOURCES ON THE INTERNET}

http://www.cedepesca.net/detalle-articulo-revista.php?id=4 (Accessed November 13rd, 2012)

http://www.seashepherd.org/espanol/espanol.html (Accessed November 13rd, 2012) 